\title{
Comparison of the ileal and faecal digestibility of dietary amino acids in adult humans and evaluation of the pig as a model animal for digestion studies in man
}

\author{
BY ANGELA M. ROWAN ${ }^{1}$, P. J. MOUGHAN ${ }^{2}$ AND M. N. WILSON ${ }^{1}$ \\ ${ }^{1}$ Department of Chemistry and Biochemistry, ${ }^{2}$ Department of Animal Science, Massey University, \\ Palmerston North, New Zealand \\ AND K. MAHER AND C. TASMAN-JONES \\ Department of Medicine, Auckland University, New Zealand
}

(Received 27 July 1992 - Revised 16 February 1993 - Accepted 4 March 1993)

\begin{abstract}
The aim of the study was to determine if there is a difference between ileal and faecal assays for determining amino acid and $\mathbf{N}$ digestibilities in adult human subjects. Comparison of true ileal amino acid and $\mathbf{N}$ digestibilities was also made between adult human subjects and growing pigs to establish the usefulness of the pig as a model animal. Five subjects with established ileostomies and six subjects with intact large bowels consumed a constant diet consisting of meat, vegetables, fruit, bread and dairy products for $\mathbf{7} \mathrm{d}$ with collection of ileostomy contents or faeces respectively over the last $\mathbf{4} \mathrm{d}$. The study was repeated using $25 \mathrm{~kg}$ body weight ileostomized and intact pigs. Apparent amino acid and N digestibility coefficients were determined. For human subjects the faecal digestibility values were significantly higher $(P<0.05)$ than the ileal values for Arg, Asp, Gly, Phe, Pro, Ser, Thr and Trp. The faecal digestibility of Met was significantly lower than the ileal value. Determination of DNA, diaminopimelic acid (DAPA) and the digestibilities of pectin, hemicellulose and cellulose in human subjects indicated that some microbial colonization had occurred at the terminal ileum after formation of an ileostomy; however, this was not as extensive as in the large intestine. True ileal amino acid and $\mathrm{N}$ digestibilities were calculated after correcting for the endogenous contribution of amino acids at the terminal ileum determined using a protein-free diet. There were no significant differences between adult human subjects and pigs for true ileal dietary amino acid digestibility except for Thr, Phe, Cys and Met. There were no significant differences between adult humans and pigs for the ileal digestibility of dry matter and the faecal digestibility of gross energy.
\end{abstract}

Amino acid digestibility : Pig: Man

The digestibility of a dietary component is an indirect measure of the net disappearance of that component from the gut. Determination of the protein and amino acid digestibilities of human food sources is an integral part of dietary protein-quality evaluation. However, there are methodological problems in determining digestibility both with respect to the most appropriate assay and the choice of model animal (FAO/WHO, 1990). Information on the digestibility of dietary proteins for man becomes particularly important when the daily intake of protein is low. This may often be the case in developing countries or for hospitalized or chronically-ill people.

The digestion of protein begins in the stomach, but occurs mainly in the small intestine. Amino acids and small peptides released by digestion are absorbed in the small intestine, with peptides being further hydrolysed intracellularly (Davenport, 1982). Undigested protein and unabsorbed peptides and amino acids, of either dietary or endogenous origin, 
enter the large intestine and are subject to digestion and metabolism by the microflora. Although some products of the microbial metabolism may be absorbed in the large intestine, it is considered that these are of limited nutritional value to the host animal, and that amino acids or peptides are not absorbed (Zebrowska, 1973; McNeil, 1988).

Studies in the pig have shown that there is generally a net breakdown of the amino acids entering the large intestine (Just, 1980), although for some amino acids, notably methionine and lysine, net synthesis may occur (Just, 1980; Low, 1980; Sauer \& Ozimek, 1986). Therefore, measures of digestibility based on the collection of faeces generally tend to overestimate the actual uptake of dietary amino acids. Faecal $\mathrm{N}$ is largely bacterial (Mason et al. 1976) and does not reflect the unabsorbed dietary component. For these reasons, dietary amino acid digestibility in farm animals is now often determined by measuring amino acid excretion at the terminal ileum rather than over the entire digestive tract (Payne et al. 1968; Zebrowska, 1973; Low, 1980; Rerat, 1981). Although the ileal measure of digestibility would also be expected to be a superior measure in man, no formal comparisons of ileal and faecal amino acid digestibility have been made in human subjects.

The aim of the present study, which included total collection of faeces and ileal digesta, was to compare ileal and faecal estimates of amino acid digestibility for human subjects receiving a balanced mixed diet. Although the findings may be limited because only one diet was used in the study, it was considered typical of a Western diet. Ileal digesta were collected from subjects who had previously undergone an ileostomy operation. There is a potential difficulty with the use of samples from ileostomates due to interference from an established microflora at the end of the ileum (Vince et al. 1973). In the present work the ileostomate was accepted as a suitable model for man to provide data on ileal amino acid digestibility. Measurement was made of the activity of bacteria at the end of the ileum to provide some indication of the extent of microbial colonization. A secondary aim of the work was to evaluate the suitability of the growing pig as a model animal for man in determining ileal amino acid digestibility and the apparent faecal digestibility of dietary energy.

\section{EXPERIMENTAL}

\section{Human study}

Subjects and diet. Ethics approval was obtained from the Auckland Hospital Human Ethics Committee and the Massey University Human Ethics Committee before the start of the trial and all subjects gave their consent with full knowledge of the experimental procedure. The subjects included five healthy adult Caucasians (two women, three men) with wellestablished ileostomies ( $>1$ year), after total colectomy to treat ulcerative colitis (Brooke, $1952,1969)$, with minimal resection of the small intestine. The subjects' ages ranged from 42 to 66 years, and body weights from 55 to $85 \mathrm{~kg}$. A further six healthy adult Caucasian volunteers (three women, three men), who had normally-functioning large intestines, were also included in the study. The latter subjects' ages ranged from 22 to 60 years and weights from 60 to $80 \mathrm{~kg}$.

The subjects were requested to follow a constant diet (Table 1), which was considered acceptable to ileostomates, for the course of the study. The dietary ingredients were generally part of the normal diet of these subjects. Three different dietary consumption levels were offered to the subjects and they chose the one that they considered to be closest to their normal level of consumption. During the experimental period each subject kept an activity diary to allow energy expenditure to be estimated. All subjects were considered to be in energy balance during the study period. The daily gross nutrient intakes for each of the three dietary consumption levels, determined by chemical analysis or reference to food tables (Paul \& Southgate, 1978), are given in Table 2. Sugar and lemonade consumption 
Table 1. Three alternative diets followed by twelve human subjects, and that (diet C) given to six pigs for the determination of amino acid digestibility

\begin{tabular}{|c|c|c|c|c|}
\hline \multirow[b]{2}{*}{ Meal } & \multirow[b]{2}{*}{ Food } & \multicolumn{3}{|c|}{ Amount consumed $(\mathrm{g})$ for diet: } \\
\hline & & A & B & $\mathrm{C}$ \\
\hline \multirow{3}{*}{$\begin{array}{l}\text { Breakfast } \\
(07.00 \text { hours })\end{array}$} & Toast (wholemeal)* & 60 & 90 & 120 \\
\hline & Butter & 10 & 15 & 20 \\
\hline & Marmaladet & 10 & 15 & 20 \\
\hline \multirow{6}{*}{$\begin{array}{l}\text { Lunch } \\
\text { (12.00 hours) }\end{array}$} & Bread (wholemeal)* & 49 & 74 & 98 \\
\hline & Butter & 10 & 15 & 20 \\
\hline & Tomato & 110 & 160 & 220 \\
\hline & Sao crackers $\$$ & 10 & 15 & 20 \\
\hline & Cheddar cheese & 45 & 68 & 90 \\
\hline & Banana\| & 150 & 225 & 300 \\
\hline Snack & Plain biscuit & 8 & 12 & 16 \\
\hline \multirow{6}{*}{$\begin{array}{l}\text { Dinner } \\
\text { (18.00 hours) }\end{array}$} & Chicken & 100 & 150 & 200 \\
\hline & Potato (peeled) & 100 & 150 & 200 \\
\hline & Carrots (peeled) & 100 & 150 & 200 \\
\hline & Frozen peas** & 60 & 90 & 120 \\
\hline & Frozen green beans** & 70 & 105 & 140 \\
\hline & Apple $+\dagger$ & 130 & 190 & 260 \\
\hline \multirow{2}{*}{\multicolumn{3}{|c|}{$\begin{array}{l}\text { Daily allowance of milk (ml) }+\ddagger \\
\text { Unlimited tea, coffee, lemonade, water and sugars } \$\end{array}$}} & 450 & 600 \\
\hline & & & & \\
\hline
\end{tabular}

* Shand's bakery, Main Rd, Huntly, New Zealand.

$\dagger$ Craig's Breakfast Marmalade; Butland Industries Ltd, 644 Great South Rd, Ellerslie, Auckland, New Zealand.

\$ Weighed and eaten with skin.

$\S$ Arnott's Sao crackers; Arnott's Biscuits (NZ) Ltd, Saleyards Rd, Private Bag, Otahuhu, Auckland, New Zealand.

$\|$ Weighed with skin.

T Arnott's Superwine biscuits; Arnott's Biscuits (NZ) Ltd.

** Wattie's frozen peas and frozen green beans; Wattie Frozen Foods Ltd, 89 Carbine Rd, Mt Wellington, Auckland, New Zealand.

†† Red delicious apple weighed and eaten with skin.

\$. Standard homogenized milk, $3 \cdot 4 \%$ fat.

$\$$ During the faecal digestibility study these were restricted to ensure constant energy intake.

were unrestricted for the ileostomates, who kept a record of the amounts consumed; however, these foods were kept constant during the study for those subjects with an intact digestive tract to allow the digestibility of energy to be determined.

The food was prepared before the $7 \mathrm{~d}$ experimental period, with individual meal portions of each ingredient being weighed and packaged separately. The vegetables were weighed $( \pm 1.0 \mathrm{~g}$ of required weight) and supplied raw or frozen. These were subsequently boiled or steamed by each subject, and care was taken not to overcook any food. The chicken was skinless white breast meat which was cooked using $5 \mathrm{~g}$ of butter. The apples, tomatoes and bananas were weighed and only those within $\pm 10 \mathrm{~g}$ of the required weight were used, with the exact weight being recorded. These were eaten uncooked and only the banana skins and apple cores were discarded.

Experimental procedure. The human subjects remained on their fixed diet for $7 \mathrm{~d}$. During the study representative meals for a whole day were collected on five separate occasions in total. These were weighed, homogenized and frozen. After $3 \mathrm{~d}$ on the diet the ileostomy output was collected from the human ileostomate subjects at regular intervals (approximately every $2-3 \mathrm{~h}$ ) for $96 \mathrm{~h}$. After collection the ileal digesta were emptied into a 
Table 2. Daily gross intakes of selected nutrients for subjects on three alternative diets* during a study to determine amino acid digestibility values

\begin{tabular}{|c|c|c|c|}
\hline \multirow[b]{2}{*}{ Nutrient } & \multicolumn{3}{|c|}{ Daily nutrient intake $\dagger$ for diet } \\
\hline & A & B & $\mathrm{C}$ \\
\hline Protein $(\mathrm{N} \times 6.25 ; \mathrm{g})$ & $65 \cdot 7$ & 98.6 & $131 \cdot 4$ \\
\hline Energy $(\mathrm{kJ}) \ddagger$ & $5600(6000)$ & $8400(8900)$ & $11200(12000)$ \\
\hline Dietary fibre (g) & $30 \cdot 1$ & $45 \cdot 2$ & $60 \cdot 2$ \\
\hline Fat (g) & $52 \cdot 2$ & $78 \cdot 3$ & $104 \cdot 4$ \\
\hline Calcium (mg) & 903.9 & 1355.9 & $1807 \cdot 8$ \\
\hline Iron (mg) & 6.9 & $10 \cdot 4$ & $13 \cdot 8$ \\
\hline Vitamin C (mg) & $64 \cdot 2$ & $96 \cdot 3$ & 128.4 \\
\hline
\end{tabular}

* For details, see Table 1 .

$\dagger$ Calculated from Paul \& Southgate (1978) and adjusted according to Wiles et al. (1980).

‡ Gross energy determined by bomb calorimetry; values in parentheses are for the diet used during the faeces collection which differed from the ileal digesta collection period during which sugar and lemonade were unrestricted.

container with $10 \mathrm{ml} 4 \mathrm{M}-\mathrm{HCl}$ added, and kept on ice during each $24 \mathrm{~h}$ collection period. At the end of each $24 \mathrm{~h}$ period the material was weighed and frozen.

For human subjects with an intact intestinal tract, all faeces voided were collected over $5 \mathrm{~d}$, with collection commencing at the end of the first $3 \mathrm{~d}$ of the $7 \mathrm{~d}$ dietary period. Faeces were weighed and frozen $\left(-20^{\circ}\right)$ within $1 \mathrm{~h}$ of collection.

Diet, ileal digesta and faeces samples for each subject were thoroughly mixed, freezedried, finely ground $(1 \mathrm{~mm})$, and stored at $-20^{\circ}$ for subsequent chemical analysis.

\section{Pig study}

Animals and surgery. Six healthy, $25 \mathrm{~kg}$ live weight, entire male pigs, Landrace $\times$ (Landrace $\times$ Large White), were surgically prepared with ileostomies using a method similar to that described by Brooke (1969). The surgery is described in detail by Rowan (1989). Each animal was anaesthetized with halothane- $\mathrm{O}_{2}$ (Fluothane; Abbott Laboratories Limited, Queensborough, Kent) administered by a mask. An oblique right lateral abdominal incision was made through which the stoma was to be formed and a $50 \mathrm{~mm}$ incision was made through the skin, muscle layers and peritoneum using cutting quartery, $30 \mathrm{~mm}$ posterior to the rib cage. The ileo-caecal junction was located and a loop of ileum exteriorized as close to the junction as possible. Where the ileo-caecal fold ended (50-100 $\mathrm{mm}$ from the ileo-caecal junction) the ileum and common mesentery were divided between vascular arcades so that the ileal blood supply was preserved. The distal end was closed by suturing the serosal edges together and was then allowed to drop back into the abdomen. The cut edge of the mesentery was attached to the parietal peritoneum of the ventral abdominal wall to avoid internal herniation, leaving about $50 \mathrm{~mm}$ of proximal ileum exposed for the formation of a stoma. A purse-string suture was placed through the mesentery and parietal peritoneum of the right iliac fossa and of the ventral abdominal wall lateral to the incision. The abdominal wall was closed in layers around the end of the ileum and relieving incisions were made if necessary in individual layers at right angles to the direction of the wound to avoid pinching of the stoma. A Duval lung-holding forceps was inserted into the ileal lumen and the intestinal wall grasped to form a fixed point so that the terminal portion could be everted. Finally the skin was sutured and, at the stoma, the cut edge of mucosa was sewn directly to the skin with one suture being placed through skin, mucosa and mesentery, so as to fix the position of the everted portion to the underlying 
ileum. The large intestine of the animal was not removed. Immediately following surgery each pig was given an intramuscular injection of antibiotic $(5 \mathrm{ml}$ Streptopen; Glaxo New Zealand Limited, Palmerston North, New Zealand). The standard human ileostomy collection bag (Combihesive; E. R. Squibb and Sons, Limited, Auckland, New Zealand) was attached over the stoma to allow complete collection of material passing from the small intestine. After surgery the pigs were given an homogenized diet consisting of a mixture of ingredients listed in Table 1, with unhomogenized food being introduced after $2 \mathrm{~d}$. Care was taken to ensure that the pigs received adequate water to avoid dehydration, and salt to avoid $\mathrm{Na}^{+}$depletion due to the ileostomy, both before and during the experimental period. Careful attention was also paid to cleanliness around the stoma and to the pig's immediate surroundings. After 2 weeks the pigs resumed normal feed intake and appeared to have recovered fully from surgery.

Experimental procedure. The six surgically-modified pigs, along with a further six pigs with normally-functioning intact large intestines, were individually caged in smooth-walled metabolism crates and housed at a temperature of $22 \pm 1^{\circ}$. All pigs were given diet $\mathrm{C}$ (Table 1), which was closest to the diet they would receive if fed on dry matter at $100 \mathrm{~g} / \mathrm{kg}$ metabolic body weight $\left(\mathrm{kg}^{0 \cdot 75}\right)$. The latter food intake was considered suitable to support normal growth in the pig. The food was cooked for all pigs at each meal-time, and care was taken to ensure that the food was prepared in the same way as for the human subjects. Representative meals for a whole day were collected on several occasions during the experimental period and were weighed, homogenized and freeze-dried as described for the human study.

The pigs received the experimental diet for $7 \mathrm{~d}$, with total ileal digesta being collected from the modified pigs from 08.00 hours on the fourth day for the following $96 \mathrm{~h}$. The ileal digesta samples were collected every $2-3 \mathrm{~h}$ and immediately placed in a container with $10 \mathrm{ml} 4 \mathrm{M}-\mathrm{HCl}$ and cooled. Faeces were collected from the intact pigs for $5 \mathrm{~d}$ commencing at the end of the first $3 \mathrm{~d}$ of the $7-\mathrm{d}$ dietary period. All faeces and digesta samples were collected, weighed, freeze dried and mixed as described for the human study. The freezedried faeces, ileal digesta and diet samples were stored at $-20^{\circ}$ for subsequent chemical analysis.

\section{Chemical analysis}

All analyses were carried out in duplicate. Total $\mathrm{N}$ was determined by the Kjeldahl technique (Hiller et al. 1948), and dry matter by drying to a constant weight in a forcedair oven at $95^{\circ}$.

Three procedures were used for hydrolysing proteins before amino acid analysis. For the determination of most amino acids except methionine, cysteine and tryptophan, but including diaminopimelic acid (DAPA) for the diet and human excreta samples, duplicate $50 \mathrm{mg}$ samples were accurately weighed into large $(30 \mathrm{ml})$ glass hydrolysis tubes and $10 \mathrm{ml}$ $6 \mathrm{M}-\mathrm{HCl}$ (containing $0.5 \mathrm{mg}$ phenol $/ \mathrm{ml}$ ) added. The tubes were evacuated and sealed, and placed in a forced-air oven at $110 \pm 2^{\circ}$ for $24 \mathrm{~h}$. The hydrolysates were made up to $50 \mathrm{ml}$, filtered, and $2 \mathrm{ml}$ evaporated to dryness. Methionine and cysteine were determined as methionine sulphone and cysteic acid respectively, after $6 \mathrm{~m}-\mathrm{HCl}$-hydrolysis of a performic acid-oxidized sample (Moore, 1963). Duplicate $50 \mathrm{mg}$ samples of the diet, ileal digesta and faeces were weighed into $250 \mathrm{ml}$ round-bottomed flasks and $2 \mathrm{ml}$ of the oxidation mixture $\left(1.0 \mathrm{ml} \mathrm{H} \mathrm{H}_{2} \mathrm{O}_{2}, 9.0 \mathrm{ml}\right.$ formic acid $(880 \mathrm{ml} / 1), 50 \mathrm{mg}$ phenol) were added and oxidation proceeded at $0^{\circ}$ for $16 \mathrm{~h}$. After oxidation, excess performic acid was degraded by adding approximately $0.84 \mathrm{~g}$ sodium metabisulphite and $50 \mathrm{ml} 6 \mathrm{M}-\mathrm{HCl}$ containing $50 \mathrm{mg}$ phenol were added to the oxidized sample which was then refluxed for $24 \mathrm{~h}$. The hydrolysate was made up to $100 \mathrm{ml}$ in a volumetric flask, filtered as described previously, and $2 \mathrm{ml}$ evaporated to dryness and stored $\left(-20^{\circ}\right)$ for analysis. For tryptophan, a separate $4.3 \mathrm{M}$ - 
LiOH-hydrolysis was performed in Teflon containers at $110 \pm 2^{\circ}$ for $20 \mathrm{~h}$. Duplicate $50 \mathrm{mg}$ samples of the diet, ileal digesta and faeces samples were weighed into Teflon containers $(30 \mathrm{ml})$, and $20 \mathrm{ml} 4.3 \mathrm{M}-\mathrm{LiOH}$ containing $4.0 \mu \mathrm{mol} 5$-methyltryptophan as an internal standard were added. $\mathrm{N}_{2}$ gas was bubbled into the top of the container and the lid replaced and tightened. Hydrolysis proceeded at $110 \pm 2^{\circ}$ for $20 \mathrm{~h}$. The hydrolysates were made up to $25 \mathrm{ml}$, filtered, and $7 \mathrm{ml}$ of the filtrate were adjusted to $\mathrm{pH} 4.5$ then made up to $10 \mathrm{ml}$ and stored at $-20^{\circ}$ for subsequent analysis.

Amino acids in the hydrolysates were determined using a Beckman $119 \mathrm{BL}$ amino acid analyser which had been calibrated using a Beckman calibration mixture. The tryptophan values were corrected for losses during hydrolysis by reference to 5-methyltryptophan recoveries (Rowan et al. 1989). The diet, ileal digesta and faeces samples were corrected for loss or incomplete hydrolysis of amino acids by using correction factors reported in a separate study (Rowan et al. 1992).

The diet, human ileal digesta and faeces samples were also analysed for DNA and dietary fibre fractions. The DNA determinations were based on the methods of Schmidt \& Thannhauser (1945) and Giles \& Myers (1965). The individual fibre components were separated using the method of Southgate (1981), and the component monosaccharides measured either as alditol acetate derivatives by GLC (Englyst \& Cummings, 1984), for pectin and hemicellulose constituents, or by determination of reducing sugars using dinitrosalicylic acid (Miller, 1959), for cellulose. Uronic acids were determined using a colorimetric method (Englyst \& Hudson, 1987). The methods used for DNA and fibre component determinations have been described fully (Rowan, 1989).

The gross energy contents of the diet, human and pig faecal samples were determined, after pelleting, using an adiabatic bomb calorimeter (A. Gallenkamp and Co. Ltd, London).

\section{Analysis of data}

Apparent ileal and faecal amino acid, N, fibre and energy digestibility coefficients were calculated using the following equation:

$$
\text { apparent digestibility }=\frac{\mathrm{CI}-\mathrm{CE}}{\mathrm{CI}},
$$

where $\mathrm{CI}$ is the amount of component eaten $(\mathrm{g} / \mathrm{d}), \mathrm{CE}$ is the amount of component excreted in ileal digesta or faeces $(\mathrm{g} / \mathrm{d})$.

True ileal amino acid digestibility coefficients were calculated by correcting the corresponding apparent values for the ileal endogenous amino acid component. The latter was determined in a separate study (Rowan, 1989; Rowan et al. 1993) which involved feeding human ileostomates and ileostomized pigs a protein-free meal. The coefficients were calculated using the following equation:

$$
\text { True amino acid digestibility }=\frac{\mathrm{AAI}-(\mathrm{AAE}-\mathrm{EAA})}{\mathrm{AAI}},
$$

where AAI is amino acid eaten (g/d), AAE is amino acid excreted (g/d), EAA is flow of endogenous amino acid $(\mathrm{g} / \mathrm{d})$.

The amino acid, $\mathrm{N}$, fibre, dry matter and gross energy digestibility coefficients, and the DNA and DAPA concentrations and flows, were subjected to a one-way analysis of variance within species and digestibility type (Snedecor \& Cochran, 1982).

\section{RESULTS}

All subjects completed the trial without complication, and complied with the experimental protocol. The retrospective energy expenditure estimates indicated that all subjects were in 
Table 3. Mean apparent ileal and faecal amino acid and nitrogen digestibility coefficients, for adult humans ( $65 \mathrm{~kg}$ body weight) receiving a meat-vegetable-cereal-dairy product-based diet $\dagger$

\begin{tabular}{|c|c|c|c|c|}
\hline & $\begin{array}{l}\text { Ileal } \\
(n 5)\end{array}$ & $\begin{array}{c}\text { Faecal } \\
(n 6)\end{array}$ & $\mathrm{SE}_{+}^{+}$ & $\begin{array}{c}\text { Statistical } \\
\text { significance } \\
\text { of difference }\end{array}$ \\
\hline \multicolumn{5}{|l|}{ Amino acid } \\
\hline Lysine & 0.936 & 0.932 & 0.0101 & NS \\
\hline Arginine & 0.902 & 0.926 & 0.0080 & $*$ \\
\hline Histidine & 0.902 & 0.922 & 0.0143 & NS \\
\hline Aspartate & 0.873 & 0.897 & 0.0089 & $*$ \\
\hline Serine & 0.865 & 0.919 & 0.0145 & $* * *$ \\
\hline Threonine & 0.847 & 0.888 & 0.0129 & $* *$ \\
\hline Glutamate & 0.936 & 0.946 & 0.0049 & NS \\
\hline Proline & 0.899 & 0.946 & 0.0132 & $* *$ \\
\hline Glycine & 0.715 & 0.865 & 0.0389 & $* * *$ \\
\hline Alanine & 0.881 & 0.879 & 0.0080 & NS \\
\hline Valine & 0.897 & 0.909 & 0.0068 & NS \\
\hline Isoleucine & 0.909 & 0.906 & 0.0060 & NS \\
\hline Leucine & 0.919 & 0.928 & 0.0054 & NS \\
\hline Tyrosine & 0.887 & 0.901 & 0.0068 & NS \\
\hline Phenylalanine & 0.896 & 0.913 & 0.0071 & $* * *$ \\
\hline Cysteine & 0.855 & 0.907 & 0.0169 & NS \\
\hline Methionine & 0.931 & 0.833 & 0.0252 & $* * *$ \\
\hline Tryptophan & 0.767 & 0.826 & 0.0250 & $*$ \\
\hline $\mathrm{N}$ & 0.869 & 0.889 & 0.0097 & NS \\
\hline \multicolumn{5}{|c|}{$\begin{array}{l}\text { NS, not significant. } \\
{ }^{*} P<0 \cdot 05, * * P<0 \cdot 01, * * * P<0 \cdot 001 \\
\dagger \text { For details of diets, see Table } 1 . \\
+ \text { Standard deviation }\end{array}$} \\
\hline
\end{tabular}

energy balance for the duration of the study. The daily flows of wet and dry matter output for the ileostomy subjects ranged from 494 to $1036 \mathrm{~g}$ and from 52 to $76 \mathrm{~g}$ respectively. For the intact human subjects, wet and dry faeces outputs were 91-224 g and 28-39 g respectively.

The ileostomized pigs remained healthy post-surgery and throughout the digesta collection period, with no signs of infection or illness. They had normal appetites and gained in weight over the 3 weeks following surgery. At the completion of the study the pigs were killed, and examination of the gut revealed that the large intestine had regressed in size and was paler in colour, but appeared healthy and still contained some digesta. Only one pig showed adhesions around the abdominal incision, and from parts of the small intestine to other parts of the intestine, but the stomas were healthy in all pigs. The daily flows of wet and dry matter output for the ileostomized pigs ranged from 1138 to $1309 \mathrm{~g}$ and $87-101 \mathrm{~g}$ respectively. For the intact pigs, wet and dry faeces outputs were $360-559 \mathrm{~g}$ and $24-37 \mathrm{~g}$ respectively. The pig faeces and ileal digesta had higher moisture contents than the respective human samples, although the total dry matter outputs relative to dry matter intake were similar for the two species.

The mean apparent ileal and faecal amino acid and $\mathrm{N}$ digestibility coefficients for adult humans are given in Table 3. There were significant $(P<0.05)$ differences between the ileal and faecal estimates for the amino acids arginine, aspartate, glycine, phenylalanine, 
Table 4. Mean concentrations ( $\mathrm{mg} / \mathrm{g}$ dry matter) in faeces and ileal digesta and daily excretions $(\mathrm{mg} / \mathrm{d})$ of $D N A$ and diaminopimelic acid $(D A P A)$, and apparent digestibilities of pectin, hemicellulose and cellulose for adult humans $(65 \mathrm{~kg}$ body weight $)$ receiving a meat-vegetable-cereal-dairy product-based diet $\dagger^{-}$

\begin{tabular}{|c|c|c|c|c|}
\hline & $\begin{array}{l}\text { Ileal } \\
(n 5)\end{array}$ & $\begin{array}{c}\text { Faecal } \\
(n 6)\end{array}$ & $\mathrm{SE}$ & $\begin{array}{c}\text { Statistical } \\
\text { significance } \\
\text { of difference }\end{array}$ \\
\hline \multicolumn{5}{|l|}{ DAPA } \\
\hline Concentration & $0 \cdot 5$ & $2 \cdot 3$ & 0.45 & $* * *$ \\
\hline Daily output & $31 \cdot 3$ & $72 \cdot 9$ & $11 \cdot 28$ & $* * *$ \\
\hline \multicolumn{5}{|l|}{ DNA-N } \\
\hline Concentration & 0.2 & 0.4 & 0.07 & $* *$ \\
\hline Daily output & $9 \cdot 8$ & $13 \cdot 3$ & $2 \cdot 04$ & $*$ \\
\hline \multicolumn{5}{|l|}{ Digestibility } \\
\hline Pectin & 0.87 & 0.95 & 0.027 & $* *$ \\
\hline Hemicellulose & 0.45 & 0.96 & $0 \cdot 126$ & $* * *$ \\
\hline Cellulose & 0.08 & 0.54 & $0 \cdot 110$ & $* * *$ \\
\hline
\end{tabular}

${ }^{*} P<0.05, * * P<0.01, * * * P<0.001$.

$\dagger$ For details of diets, see Table 1.

Table 5. Mean apparent ileal amino acid and nitrogen digestibility coefficients for ileostomized adult humans ( $65 \mathrm{~kg}$ body weight) and growing pigs ( $25 \mathrm{~kg}$ body weight) receiving a meat-vegetable-cereal-dairy product-based diet $\dagger$

\begin{tabular}{|c|c|c|c|c|}
\hline & $\begin{array}{l}\text { Human } \\
(n 5)\end{array}$ & $\begin{array}{c}\text { Pig } \\
(n 6)\end{array}$ & SE & $\begin{array}{c}\text { Statistical } \\
\text { significance } \\
\text { of difference }\end{array}$ \\
\hline \multicolumn{5}{|l|}{ Amino acid } \\
\hline Lysine & 0.936 & 0.926 & 0.0084 & NS \\
\hline Arginine & $0 \cdot 902$ & 0.921 & 0.0066 & $*$ \\
\hline Histidine & 0.902 & $0 \cdot 919$ & 0.0097 & NS \\
\hline Aspartate & 0.873 & 0.904 & 0.0093 & $* *$ \\
\hline Serine & 0.865 & 0.899 & 0.0106 & $* *$ \\
\hline Threonine & 0.847 & 0.870 & 0.0092 & NS \\
\hline Glutamate & $0 \cdot 936$ & 0.946 & 0.0044 & NS \\
\hline Proline & 0.899 & 0.868 & 0.0122 & NS \\
\hline Glycine & $0 \cdot 715$ & 0.779 & 0.0221 & $*$ \\
\hline Alanine & 0.881 & 0.889 & 0.0065 & NS \\
\hline Valine & 0.897 & 0.915 & 0.0064 & $* *$ \\
\hline Isoleucine & 0.909 & 0.928 & 0.0059 & $* *$ \\
\hline Leucine & 0.919 & 0.947 & 0.0076 & NS \\
\hline Tyrosine & $0 \cdot 887$ & 0.911 & 0.0076 & NS \\
\hline Phenylalanine & 0.896 & 0.910 & 0.0057 & $* *$ \\
\hline Cysteine & 0.855 & 0.829 & 0.0131 & $*$ \\
\hline Methionine & 0.931 & 0.905 & 0.0077 & $* *$ \\
\hline Tryptophan & 0.767 & 0.808 & 0.0231 & NS \\
\hline$N$ & 0.869 & 0.860 & 0.0072 & NS \\
\hline
\end{tabular}

NS, not significant

$* P<0.05, * * P<0.01$

$\dagger$ For details of diets, see Table 1. 
Table 6. Mean true $\dagger$ ileal amino acid and nitrogen digestibility coefficients for ileostomized adult humans ( $65 \mathrm{~kg}$ body weight) and growing pigs $(25 \mathrm{~kg}$ body weight) receiving a meat-vegetable-cereal-dairy product-based diet $\$$

\begin{tabular}{|c|c|c|c|c|}
\hline & $\begin{array}{l}\text { Human } \\
(n 5)\end{array}$ & $\begin{array}{c}\text { Pig } \\
(n 6)\end{array}$ & $\mathrm{SE}$ & $\begin{array}{c}\text { Statistical } \\
\text { significance } \\
\text { of difference }\end{array}$ \\
\hline \multicolumn{5}{|l|}{ Amino acid } \\
\hline Lysine & 0.987 & 0.975 & 0.0041 & NS \\
\hline Arginine & 0.983 & 0.977 & 0.0048 & NS \\
\hline Histidine & 0.992 & 0.975 & 0.0065 & NS \\
\hline Aspartate & 0.992 & 0.978 & 0.0061 & NS \\
\hline Serine & 0.994 & 0.995 & 0.0061 & NS \\
\hline Threonine & $1 \cdot 051$ & 0.997 & 0.0136 & $* *$ \\
\hline Glutamate & 0.985 & 0.982 & 0.0034 & NS \\
\hline Proline & 1.009 & 0.981 & 0.0113 & NS \\
\hline Glycine & 0.924 & 0.905 & 0.0128 & NS \\
\hline Alanine & 0.989 & 0.980 & 0.0048 & NS \\
\hline Valine & 0.995 & 0.986 & 0.0053 & NS \\
\hline Isoleucine & 0.995 & 0.976 & 0.0064 & NS \\
\hline Leucine & $1 \cdot 001$ & 1.008 & 0.0038 & NS \\
\hline Tyrosine & 0.992 & 0.980 & 0.0051 & NS \\
\hline Phenylalanine & 0.999 & 0.975 & $0-0069$ & $*$ \\
\hline Cysteine & 1.003 & 0.922 & 0.0195 & $* * *$ \\
\hline Methionine & 0.984 & 0.960 & 0.0064 & $* *$ \\
\hline Tryptophan & 0.991 & 0.968 & $0 \cdot 0233$ & NS \\
\hline $\mathrm{N}$ & 0.980 & 0.987 & 0.0117 & NS \\
\hline
\end{tabular}

NS, not significant.

${ }^{*} P<0.05,{ }^{* *} P<0.01,{ }^{* * *} P<0.001$.

$\dagger$ Corrected using endogenous amino acid loss for humans and pigs receiving a protein-free diet (Rowan, 1989; Rowan et al. 1993).

$\ddagger$ For details of diets, see Table 1 .

proline, serine, threonine and tryptophan, with values being higher over the entire tract than at the terminal ileum. The ileal digestibility of methionine, however, was significantly $(P<0 \cdot 001)$ higher than the faecal value.

The ileal and faecal concentrations and daily excretions of DNA and DAPA for the human subjects are given in Table 4 , along with the ileal and faecal digestibility coefficients for pectin, hemicellulose and cellulose. All faecal values were significantly higher than the corresponding ileal values.

The mean apparent and true ileal amino acid and $\mathrm{N}$ digestibility coefficients for the adult humans and growing pigs are given in Tables 5 and 6 . There were statistically significant differences between the two species for apparent digestibility for the amino acids arginine, aspartate, serine, glycine, valine, isoleucine, phenylalanine, cysteine and methionine, although the differences were all small (less than 6.3 percentage units). There were no significant differences $(P>0.05)$ between the two species for true ileal amino acid digestibility except for threonine, phenylalanine, cysteine, and methionine.

The mean faecal gross energy digestibility coefficients were 0.93 and 0.94 (SE 0.59 ) for humans and pigs respectively, and there was no significant difference $(P>0.05)$ between the two species. The ileal and faecal dry matter digestibility coefficients were 0.85 and 0.93 respectively for humans, and 0.85 and 0.95 (overall SE 0.57 ) respectively for pigs. There were significant differences $(P<0.05)$ between ileal and faecal dry matter digestibility determinations for both species, but no significant difference between the two species for either site of measurement. 


\section{DISCUSSION}

The main aim of the present study was to compare the digestibility of dietary amino acids in adult humans as determined at the terminal ileum or over the entire digestive tract. Such comparison necessitates measurement of amino acid flow at the terminal ileum, which was accomplished in the present study with the cooperation of ileostomates. There are possible limitations with the ileostomate for determining ileal digestibility values, however, due to the consequences of microbial colonization that occurs following surgery. The total number of organisms recovered from ileal effluent may be about eighty times that in normal ileal contents (Gorbach et al. 1967), and bacterial fermentation of carbohydrate has been shown to occur in the terminal ileum of ileostomates (Dowsett et al. 1990). It is not known to what extent the microflora will affect the measurement of amino acid digestibility, as this depends on the numbers and types of micro-organisms present as well as the rate of passage of digesta through that region of the gut. The transit of digesta through the small intestine is rapid (Dillard et al. 1965) and the microbial species normally found there seem to have limited ability to deaminate or decarboxylate amino acids (Drasar \& Hill, 1974). In spite of uncertainty, however, ileostomates have been widely accepted as a suitable model for in vivo human nutrition studies (Holloway et al. 1978, 1980, 1983; Sandberg et al. 1981; Sandstrom et al. 1986; Chacko \& Cummings, 1988).

In the present study, comparison of several indicators of microbial activity was made between terminal ileal digesta and faeces from ileostomates and intact humans respectively. DNA and DAPA were determined to indicate the presence of bacteria. DAPA only occurs in bacterial cell walls, although its concentration is not constant across all bacterial species and therefore the numbers of bacteria present in digesta cannot readily be determined by measuring DAPA concentration. DNA, another commonly-used microbial marker, also may be of limited use because gut cells also contain DNA. The breakdown of dietary fibre will occur only as a result of the activity of gut micro-organism enzymes because the digestive enzymes of the host cannot degrade dietary fibre. Microbial digestion of dietary fibre, however, will not necessarily occur to the same extent as the digestion of protein. DAPA output found for human subjects in the present study was similar to that reported for preruminant calves (Guilloteau et al. 1980, 1986). The ileal and faecal DNA outputs determined in the present study were higher than values reported by other workers for the pig and the chicken (Salter \& Coates, 1971; Fleming \& Wasilewski, 1984). The present results for pectin, hemicellulose and cellulose digestibilities as determined on the faeces were similar to values reported in other studies with human subjects (Holloway et al. 1978, 1980, 1983; Sandberg et al. 1981; Cummings \& Englyst, 1987). However, the present ileal digestibility values for pectin and hemicellulose were generally higher and cellulose values lower than values reported in these other studies. Based on the results for ileal and faecal DNA and DAPA outputs and the loss in the small intestine of some dietary pectin, hemicellulose and cellulose, it appears that there is some microbial activity proximal to the terminal ileum of ileostomates. However, this activity is less extensive than in the large intestine. It is possible that the numbers and activity of micro-organisms found in the small intestine of the ileostomate are higher than those in human subjects who have not undergone the operation, but this remains unknown. If the ileostomate's microflora significantly affected the determination of ileal amino acid digestibility, however, the determined digestibility coefficients would be higher than normal which would diminish the ileo-faecal difference. Consequently, it may be that ileo-faecal differences in dietary amino acid digestibility are higher than were observed here.

For approximately half the amino acids investigated the faecal measurement of digestibility was higher than the ileal measure. The overall mean difference was 3.7 percentage units, although there were differences as high as 15 percentage units. The 
digestibility values for methionine, lysine, alanine, and isoleucine at the terminal ileum were higher than those in the faeces, but were only significantly so for methionine. Although the differences between the ileal and faecal digestibility values were statistically significant for arginine, aspartate, serine, threonine, proline, glycine, phenylalanine, methionine and tryptophan, the differences in practical terms were often small (less than $5 \%$ ). Differences between the ileal and faecal digestibilities of protein for meat and soya-bean-based diets reported in different studies with human subjects (Istfan et al. 1983; Schrimshaw et al. 1983; Wayler et al. 1983; Young et al. 1984; Sandstrom et al. 1986) were slightly greater $(5-10 \%)$ than the difference found in the present study. However, Gibson et al. (1976) reported apparent ileal protein digestibilities which were similar to the apparent faecal protein digestibilities for the same diets.

The present amino acid digestibility results showed relatively low variation between subjects, with coefficients of variation ranging from 0.8 to $5.0 \%$ for glutamate and tryptophan respectively for the ileal values, and from 0.9 to $5.1 \%$ for glutamate and tryptophan respectively for the faecal values. The pig apparent ileal digestibility data and the human data showed similar variability. Because of the small ileo-faecal differences found here there may be little advantage in using an ileal assay with human subjects. Faecal estimates of amino acid digestibility, which are easier to obtain, may be sufficiently accurate for most practical applications. However, it must be appreciated as discussed previously that use of the ileostomate may lead to underestimation of the real ileo-faecal differences. Also, the diet used in the present study was of high overall digestibility and greater ileofaecal differences for amino acid digestibility are expected for more poorly digested foods (Sauer et al. 1980). Taking the present results and based on the latter considerations it would appear that, in line with findings in a number of other single-stomached animal species, the ileal amino acid digestibility assay is more accurate than the faecal method with adult human subjects. It would also appear that the microflora present in the hindgut of adult human subjects may have a small but significant effect on dietary protein digestion.

It is becoming increasingly difficult for ethical reasons to carry out research using human subjects and this is particularly true for the more routine work of food evaluation. Therefore, when attempting to determine the amino acid digestibility of human foodstuffs, whether as individual ingredients or as a mixed diet, it would be more appropriate to use a model animal to allow routine and controlled studies. Several animal species have been used as models in the area of clinical nutrition, but few direct comparisons have been made to establish the usefulness of the animals as models for predicting protein digestibility in human diets. Forsum et al. (1981) investigated the protein quality of two mixed diets and compared true faecal protein digestibilities between adult humans, the growing pig $(12 \mathrm{~kg})$ and the growing laboratory rat. The comparison was somewhat marred, however, in that the three species did not receive exactly the same diets over the experimental period, and the endogenous protein contribution in the gut was determined using different procedures in the different species. The true digestibilities for the vegetable-protein diet were 80,85 and $85 \%$, and for the vegetable-animal-protein diet were 88,90 and $90 \%$ for the human, pig and rat respectively. Although the values were similar, Forsum et al. (1981) suggested that the growing pig should be further investigated for evaluation of human diets because there are often practical problems with feeding rats human diets of poor-protein quality. The pigs used in the latter study, however, were immature animals, being only $12 \mathrm{~kg}$ live weight, and larger pigs may be better models for the adult human. The pig may also be a better model animal than the rat because the pig is a meal-eating species and does not practice coprophagy as does the rat. Several workers have claimed that the pig is an acceptable model for human nutrition studies (Pond \& Houpt, 1978; Dodds, 1982; Rerat, 1984; Fleming \& Wasilewski, 1984; Miller \& Ullrey, 1987) and the two species have a similar gastrointestinal anatomy and physiology (Moughan \& Rowan, 1989). 
In the present study, differences between adult humans and growing pigs for the apparent ileal digestibilities of amino acids were small (range $0 \cdot 7-6.3$ percentage units for alanine and glycine respectively), although significant $(P<0.05)$ for arginine, aspartate, serine, glycine, valine, isoleucine, phenylalanine, cysteine and methionine. Comparison of the true ileal digestibility values for amino acids and $\mathrm{N}$ between humans and the pig also showed little difference (range $0 \cdot 3-8 \cdot 1$ percentage units for serine and cysteine respectively), with differences being statistically significant only for threonine, phenylalanine, cysteine and methionine. The true digestibility coefficient for threonine was greater than unity, which may indicate overestimation of endogenous ileal threonine excretion with the protein-free feeding regimen. Only the species difference for cysteine was of practical significance. It is concluded, therefore, that the present findings support the use of the pig as a model animal to allow routine determination of the true ileal digestibilities of amino acids and $\mathrm{N}$ in foods for humans. The results also indicate that the pig may provide a useful model for determining the digestible energy content of human foods. Further work needs to be conducted, using a wider range of foods, to test further the adequacy of the pig as a model animal.

In conclusion, the present study provides evidence for a difference between the ileal and faecal assays for determining dietary amino acid digestibility in humans. The growing domestic pig would appear to be a useful model animal for humans in the determination of dietary protein digestibility.

The authors are grateful to the Auckland and Manawatu Ostomy Societies for their ready involvement in the present study. The authors also thank Dr D. Carr for performing the animal surgery, Dr C.S. W. Reid and Mrs I. Hall for assistance with surgery and Dr G. Midwinter, Mr J. Reid and Mr G. Pearson for technical assistance.

\section{REFERENCES}

Brooke, B. N. (1952). The management of an ileostomy including its complications. Lancet ii, 102-104.

Brooke, B. N. (1969). In Operative Surgery, vol. 5, pp. 515-521 [C. Rob, R. Smith and C. N. Morgan, editors]. London: Butterworths.

Chacko, A. \& Cummings, J. H. (1988). Nitrogen losses from the human small bowel: obligatory losses and the effect of physical form of food. Gut 29, 809-815.

Cummings, J. H. \& Englyst, H. N. (1987). Fermentation in the human large intestine and the available substrates. American Journal of Clinical Nutrition 45, 1243-1255.

Davenport, H. W. (1982). Physiology of the Digestive Tract. Chicago and London: Yearbook Medical Publishers, Inc.

Dillard, R. L., Eastman, H. \& Fordtran, J. S. (1965). Volume-flow relationship during the transport of fluid through the human small intestine. Gastroenterology 49, 58-66.

Dodds, W. J. (1982). The pig model for biomedical research. Federation Proceedings 41, 247-256.

Dowsett, J., Gibney, M. J. \& Kennedy, N. P. (1990). Bacterial fermentation occurs in the terminal ileum of ileostomates. Proceedings of the Nutrition Society 49, 110A.

Drasar, B. S. \& Hill, M. J. (1974). Human Intestinal Flora. New York and London: Academic Press.

Englyst, H. N. \& Cummings, J. H. (1984). Simplified method for the measurement of total non-starch polysaccharides by gas--liquid chromatography of constituent sugars as alditol acetates. Analyst 109, 937-942.

Englyst, H. N. \& Hudson, G. J. (1987). Colorimetric method for routine measurement of dietary fibre as nonstarch polysaccharides. A comparison with gas-liquid chromatography. Food Chemistry 24, 63-67.

FAO/WHO (1990). Report of the Joint FAO/WHO Expert Consultation on Protein Quality Evaluation. Rome: Food and Agriculture Organization of the United Nations.

Fleming, S. E. \& Wasilewski, M. M. (1984). Using the pig as a tool for studying fermentation in the gut. Nutrition Reports International 30, $825-834$.

Forsum, E., Goranzon, H., Rundgren, M., Thilen, M. \& Hambraeus, L. (1981). Protein evaluation of mixed diets. Comparative study in man and the pig and rat of vegetable-animal and vegetable protein diets. Annals of Nutrition and Metabolism 25, 137-150.

Gibson, J. A., Sladen, G. E. \& Dawson, A. M. (1976). Protein absorption and ammonia production: the effects of dietary protein and removal of the colon. British Journal of Nutrition 35, 61-65.

Giles, K. W. \& Myers, A. (1965). An improved diphenylamine method for the estimation of deoxyribonucleic acid. Nature 206, 93. 
Gorbach, S. L., Nahas, L., Weinstein, L., Levitan, R. \& Patterson, J. F. (1967). Studies of intestinal microflora. IV. The microflora of ileostomy effluent: a unique microbial ecology. Gastroenterology 53, 874-880.

Guilloteau, P., Patureau-Mirand, P., Toullec, R. \& Prugnard, J. (1980). Digestion of milk protein and methanolgrown bacterial protein in the preruminant calf. 2 . Amino acid composition of ileal digesta and faeces and blood levels of free amino acids Reproduction, Nutrition, Development 20, 615-629.

Guilloteau, P., Toullec, R., Grongnet, J. F., Patureau-Mirand, P., Prugnard, J. \& Sauvant, D. (1986). Digestion of milk, fish, soya-bean protein in the pre-ruminant calf: flow of digesta, apparent digestibility at the end of the ileum and amino acid composition of ileal digesta. British Journal of Nutrition 55, 571-592.

Hiller, A., Plazin, J. \& Van Slyke, D. D. (1948). A study of conditions for kjeldahl determination of nitrogen in proteins. Description of methods with mercury as catalyst and titrimetric and gasometric measurements of the ammonia formed. Journal of Biological Chemistry 176, 1401-1420.

Holloway, W. D., Tasman-Jones, C. \& Bell, E. (1980). The hemicellulose component of dietary fibre in humans. American Journal of Clinical Nutrition 33, 260-263.

Holloway, W. D., Tasman-Jones, C. \& Lee, S. P. (1978). Digestion of certain fractions of dietary fibre in humans. American Journal of Clinical Nutrition 31, 927-930.

Holloway, W. D., Tasman-Jones, C. \& Maher, K. (1983). Pectin digestion in humans. American Journal of Clinical Nutrition 37, 253-255.

Istfan, N., Murray, E., Tanghorbani, M. \& Young, V. R. (1983). An evaluation of the nutritional value of a soy protein concentrate in young adult men using the short-term N-balance method. Journal of Nutrition 113 , 2516-2523.

Just, A. (1980) In Current Concepts of Digestion and Absorption in the Pig, pp. 66-75 [A. G. Low and I. G. Partridge, editors]. Reading: NIRD.

Low, A. G. (1980). Nutrient absorption in pigs. Journal of the Science of Food and Agriculture 31, 1087-1130.

McNeil, N. I. (1988). Nutritional implications of human and mammalian large intestinal function. World Review of Nutrition and Dietetics 56, 1-42.

Mason, V. C., Just, A. \& Bech-Andersen, S. (1976). Bacterial activity in the hind-gut of pigs. 2. Its influence on the apparent digestibility of nitrogen and amino acids. Zeitschrift für Tierphysiologie, Tierernahrung und Futtermittelkunde 36, 310-324.

Miller, E. R. \& Ullrey, D. E. (1987). The pig as a model for human nutrition. Annual Reviews of Nutrition 7 , $361-382$.

Miller, G. L. (1959). Use of dinitrosalicylic acid reagent for the determination of reducing sugar. Analytical Chemistry 31, 426-428.

Moore, S. (1963). The determination of cystine as cysteic acid. Journal of Biological Chemistry 238, $235-237$.

Moughan, P. J. \& Rowan, A. M. (1989). The pig as a model animal for human nutrition research. Proceedings of the Nutrition Society of New Zealand 14, 116-124.

Paul, A. A. \& Southgate, D. A. T. (1978). McCance and Widdowson's The Composition of Foods, pp. 1-418. London: HM Stationery Office.

Payne, W. L., Combs, G. F., Kifer, R. R. \& Snyder, D. G. (1968). Investigation of protein quality - ileal recovery of amino acids. Federation Proceedings 27, 1199-1203.

Pond, W. G. \& Houpt, K. A. (1978). The Biology of the Pig. Ithaca, NY: Comstock Publishing Associates.

Rerat, A. (1981). Digestion and absorption of nutrients in the pig. Some new data concerning protein and carbohydrates. World Review of Nutrition and Dietetics 37, 229-287.

Rerat, A. (1984). In Function and Dysfunction of the Small Intestine. Proceedings of the 2nd George Durrant Memorial Symposium, p. 22. [R. M. Batt and T. L. J. Lawrence, editors]. Liverpool: Liverpool University Press.

Rowan, A. M. (1989). A study of the digestion of protein in humans using ileal and faecal assays. MSc Thesis, Massey University, Palmerston North, New Zealand.

Rowan, A. M., Moughan, P. J. \& Wilson, M. N. (1989). Alkaline hydrolysis for the determination of tryptophan in biological samples. Proceedings of the Nutrition Society of New Zealand 14, 169-172.

Rowan, A. M., Moughan, P. J. \& Wilson, M. N. (1992). Effect of hydrolysis time on the determination of the amino acid composition of diet, ileal digesta, and feces samples and on the determination of dietary amino acid digestibility coefficients. Journal of Agricultural and Food Chemistry 40, 981-985.

Rowan, A. M., Moughan, P. J. \& Wilson, M. N. (1993). Endogenous amino acid flow at the terminal ileum of adult humans determined following the ingestion of a single protein-free meal. Journal of the Science of Food and Agriculture 61, 439-442.

Russell, C. A., Evans, S. J. \& Mabbutt, C. (1984). A comparison of the absorption of nitrogen from "chemicallydefined elemental" or "whole-protein" enteral feeds by the human small bowel. Proceedings of the Nutrition Society 43, 123A.

Salter, D. N. \& Coates, M. E. (1971). The influence of the microflora of the alimentary tract on protein digestion in the chick. British Journal of Nutrition 26, 55-61.

Sandberg, A., Andersson, H., Hallgren, B., Hasselblad, K., Isaksson, B. \& Hulten, L. (1981). Experimental mode] for in vivo determination of dietary fibre and its effects on the absorption of nutrients in the small intestine. British Journal of Nutrition 45, 283-294.

Sandstrom, B., Andersson, H., Kivisto, B. \& Sandberg, A. S. (1986). Apparent small intestinal absorption of nitrogen and minerals from soy and meat-protein based diets. Journal of Nutrition 116, 2209-2218. 
Sauer, W. C., Just, A., Jorgensen, H. H., Fekadu, M. \& Eggum, B. O. (1980). The influence of diet composition on the apparent digestibility of crude protein and amino acids at the terminal ileum and overall in pigs. Acta Agricultura Scandinavica 30, 449-459.

Sauer, W. C. \& Ozimek, L. (1986). Digestibility of amino acids in swine: results and their practical applications. A review. Livestock Production Science 15, 367-388.

Schmidt, G. \& Thannhauser, S. J. (1945). A method for the determination of deoxyribonucleic acid, ribonucleic acid, and phosphoproteins in animal tissues. Journal of Biological Chemistry 161, 83-89.

Schrimshaw, N. S., Wayler, A. H., Murray, E., Steinke, F. H., Rand, W. M. \& Young, V. R. (1983). Nitrogen balance in young men given one of two isolated soy proteins or milk protein. Journal of Nutrition 113, 2492-2497.

Snedecor, G. W. \& Cochran, W. G. (1982). Statistical Methods. Iowa: Iowa State University Press.

Southgate, D. A. T. (1981). In The Analysis of Dietary Fibre in Foods, pp. 1-21 [W. P. T. James and O. Theander, editors]. New York and Basel: Marcel Dekker, Inc.

Vince, A., O'Grady, F. \& Dawson, A. M. (1973). The development of ileostomy flora. Journal of Infectious Diseases 128, 638-641.

Wayler, A., Queiroz, E., Schrimshaw, N. S., Steinke, F. H., Rand, W. M. \& Young, V. R. (1983). Nitrogen balance studies in young men to assess the protein quality of an isolated soy protein in relation to meat proteins. Journal of Nutrition 113, 2485-2491.

Wiles, S. J., Nettleton, P. A., Black, A. E. \& Paul, A. A. (1980). The nutrient composition of some cooked dishes eaten in Britain: A supplementary food composition table. Journal of Human Nutrition 34, 189-223.

Young, V. R., Puig, M., Queiroz, E., Schrimshaw, N. S. \& Rand, W. M. (1984). Evaluation of the protein quality of an isolated soy protein in young men: relative nitrogen requirements and effect of methionine supplementation. American Journal of Clinical Nutrition 39, 16-24.

Zebrowska, T. (1973). Influence of dietary protein source on the rate of digestion in the small intestine of pigs. Part II. The rate of protein digestion and amino acid absorption. Roczniki Nauk Rolniczych B 95, 135-155. 